РОЗВИТОК СИСТЕМИ МОРСЬКОЇ ОСВІТИ В УКРАЇНІ

\title{
DEVELOPMENT OF THE MARINE EDUCATION SYSTEM IN UKRAINE
}

У статті на основі теоретичних узагальнень розглянуто основні аспекти розвитку системи морської освіти та ї̈ періодизацію. Докладно проаналізовано період, хронологічно співвіднесений із добою незалежності України. Автором визначено пріоритетні напрями системи морської освіти в Україні. До них віднесено: глобалізацію і різноаспектний розвиток морської освіти з поглибленням ії теоретичних засад $і$ розширенням практичного досвіду; кореляцію змісту робочих програм навчальних дисциплін із вимогами міжнародних стандартів і конвенцій; спрямованість на забезпечення безпеки судноплавства як через неухильне дотримання правил техніки безпеки, безаварійність, так і через застосування пристроїв і обладнання, що забезпечують екологічну ефективність; посилення уваги до мовної освіти, зміщення акцентів у мовленнєвій підготовці студентів і занурення їх у профресійний і полікультурний контексти; підготовка студентів до профресійно й соціально відповідальної комунікації, зумовленої національно змішаними колективами; застосування в освітньому процесі інноваційних педагогічних технологій, спрямованих на фрормування ключових і професійних компетентностей випускників.

Досліджено, що українські заклади морської освіти мають давні традиції відповідно до національних стандартів, але враховують вимоги міжнародних стандартів. Прикметною ознакою сучасних закладів морської освіти є тісна міжнародна співпраця. Зазначено, що всі вітчизняні заклади морської освіти мають угоди з різноманітними міжнародними організаціями й установами.

Вивчення досвіду роботи сучасних закладів морської освіти, спостереження за освітнім процесом уможливили виокремлення провідних напрямів їхньої діяльності.

Визначено перспективи подальших досліджень, що полягають у вивченні потенціалу морської освіти в контексті експорту освітніх послуг з огляду на відкритість світового ринку праці морських фрахівців.

Ключові слова: морська освіта, періодизація розвитку морської освіти, напрями системи морської освіти.
In the article on the basis of theoretical generalizations the main aspects of development of the marine education system its periodization are considered. The period, which is chrono logically correlated with the days of Ukraine's independence, is analyzed in detail. The author identifies priority areas of the maritime education system in Ukraine. These include: globalization and multifaceted development of maritime education with deepening of its theoretical foundations and broadening of practical experience; correlation of the content of the work programs of the academic disciplines with the requirements of international standards and conventions; focus on ensuring the safety of navigation, both through the strict adherence to safety rules, safety, and through the use of devices and equipment that provide environmental performance; increasing the focus on language education, shifting the emphasis in students' language training and immersing them in professional and multicultural contexts preparation of students for professionally and socially responsible communication caused by nationally mixed teams; application of innovative pedagogical technologies in the educational process, aimed at forming key and professional competences of graduates.

It has been researched that Ukrainian maritime education institutions have a long tradition in accordance with national standards, while complying with the requirements of international standards. A prominent feature of modern maritime education institutions is close international cooperation. It is noted that all domestic maritime education institutions have agreements with various international organizations and institutions.

Studying the experience of modern maritime education institutions, observing the educational process made it possible to identify the leading areas of their activity

The prospects for further research, which are to explore the potential of maritime education in the context of export of educational services with a view to the openness of the marine labor market, have been determined.

Key words: maritime education, periodization of maritime education development, directions of maritime education system.
Постановка проблеми у загальному вигляді. Розвиток України як морської держави, динамічні глобалізаційні процеси, що відбуваються в усіх галузях, зокрема морській, зумовлюють посилення уваги дослідників до проблем підготовки здобувачів морської освіти.

Питання ефективного фрункціонування системи морської освіти відображені в законодавчих і нормативних документах (Законах України «Про освіту» (2017), «Про вищу освіту» (2014), проекті Закону «Про профресійну (профресійно-технічну) освіту» (2018), Національній стратегії розвитку освіти в Україні на період до 2021 р. (2013), Морській доктрині України на період до 2035 р. (2009), проекті реформування освітньої галузі в Україні та проекті Концепції розвитку освіти до 2025 р.).
Стратегічними документами, які покладено в основу розвитку освітньої політики України на світовому рівні, $€$ «Всесвітня програма дій у галузі освіти з прав людини та демократії» (Монреаль, 1993 р.), «Декларація Міністрів, прийнята на 44-й сесії Міжнародної конвенції з питань освіти» (Женева, 1994 р.), «нтегровані рамки дій у галузі освіти в дусі миру, прав людини та демократії» (Париж, 1995 р.), Міжнародна стандартна класифрікація освіти (МСКО, ЮНЕСКО, 1997), а також постанови Кабінету Міністрів України «Про основні напрями реорормування системи підготовки спеціалістів і працевлаштування випускників вищих навчальних закладів» та ін.

Мета статті полягає у розгляді основних аспектів розвитку системи морської освіти та визначенні 
пріоритетних напрямів системи морської освіти в Україні.

Аналіз останніх досліджень і публікацій. Сьогодні $\epsilon$ значні напрацювання, що стосуються підготовки фрахівців для фрлоту (А. Василевич, Л. Герганов, О. Данилова, Т. Демченко, 3. Орлова, В. Пірко, В. Постолатій, Л. Прокопенко, Н. Рижева, Н. Слюсаренко, Т. Сухова, О. Тимофрєєва, О. Чагайда та ін.). З'явилася низка дисертаційних праць, у яких автори (М. Алпатов, М. Бабишена, Ю. Бордученко, Т. Гульчук, А. Зуєв, Л. Герганов, А. Кондуков, М. Кулакова, А. Ляшкевич, Я. Нагрибельний, І. Сокол, А. Солодовник, О. Чорний та ін.) розглядають певні аспекти названої проблеми, які також підкреслюють її актуальність.

Незважаючи на значну кількість праць, поза увагою дослідників залишається проблема розвитку системи морської освіти в педагогічному контексті, що й зумовлює актуальність нашої розвідки.

Виклад основного матеріалу. Ознайомлення $з$ історією морської освіти має велике значення для курсантів - здобувачів морської освіти, оскільки опанування історичних відомостей сприяє формуванню гордості за свою професію, їі кращих представників. Сьогодні виникла гостра потреба осмислити історію морської освіти в контексті національної культури.

Аналіз спеціальних джерел свідчить: шлях становлення й розвитку морської освіти складний, почасти суперечливий, що зумовлено історико-соціальним контекстом, з одного боку, а з іншого - складністю проблеми, оскільки професійна підготовка морського фрахівця - явище системне й багатовекторне, яке поєднує фрормування ціннісного ставлення до професії, знання й уміння в галузі морської історії, гідрографрії, навігації, морської стратегії й тактики тощо. Нам імпонує наукова позиція О. Тимофеєєвої: «Нині відповідно до вимог Міжнародної конвенції про підготовку, дипломування моряків і несення вахти (STCW/95) в умовах сьогодення нагальною $€$ потреба у фрахівцях морського фрлоту з високим рівнем сформованості соціально-комунікативної компетентності. Це зумовлено особливостями самої профресії, вимогами до професійної мобільності моряків і міжнародним ринком їхньої праці» [4].

У дослідженні було використано такі методи: аналіз і синтез фрілософської, педагогічної й психологічної літератури, що дають змогу уточнити основні поняття дослідження; хронологічний, порівняльно-історичний, які дозволили у хронологічній послідовності відтворити ґенезу розвитку морської освіти, здійснити порівняльне вивчення підходів до періодизації морської освіти; періодизацію, узагальнення, систематизацію наукових фрактів - для викладення й інтерпретації історикопедагогічного матеріалу.

Логіка нашого дослідження передбачала осмислення семантики поняття «морська освіта».
Морську освіту як процес дослідники (Л. Герганов, В. Кузьменко, А. Ляшкевич, І. Сокол, О. Тимофрєєва та ін.) характеризують тяглістю в часі, технологічністю, різницею між вихідним (стартовим) і кінцевим (результатом) станами учасників. Водночас, як і будь-яка інша, морська освіта є системою, що має певну структуру та ієрархію її складників. На думку А. Ляшкевич: «Морська освіта як форма організації учіння та здобуття професії, з одного боку, характеризується наявністю сукупності взаємозалежних структурних і фрункціональних компонентів (таких частин системи, взаємодія яких 3 іншими частинами призводить до утворення системних властивостей) і сукупністю елементів (технічних об'єктів, які недоцільно розбивати на частини)». До складників означеної системи дослідниця відносить мету, що відтворюється в загальних і специфічних цілях; зміст освіти, відбір якого залежить від соціального замовлення та суспільно-історичних умов; форми, методи і засоби навчання, виховання й розвитку; результат учіння; суб'єктів освітнього процесу. Водночас науковець зауважує: ця система містить складники, «пов'язані в ієрархічну структуру, прямими та зворотними зв'язками, емерджентні властивості, просторове розміщення, підсистему управління; їй притаманні самоорганізація, мультиплікативність та адаптивність - і тому ії можна віднести до розряду соціально-економічних систем» [2, с. 48].

3-поміж науковців немає одностайності щодо періодизації морської освіти в Україні. Наприклад, О. Тимофрєєва виокремлює чотири періоди морської освіти:

- перший - кінець XV - кінець XVIII ст.;

- другий - кінець XVIII ст. - 1917 р.;

- третій - радянський - 1917-1991 рр.;

- четвертий - 1991 р. - донині [4].

3 історичних джерел відомо, що становлення морської освіти припадає на кінець XV ст. - час організації відбиття нападів Оттоманської Порти, створення першої козацької фрлотилії. На думку О. Тимофрєєвої: «У перший період розвитку морської освіти вона мала загалом практичну спрямованість, козаки були універсальними воїнами, готовими бути одночасно і сухопутними воїнами, і морськими піхотинцями. При їх підготовці особливу увагу звертали на фрізичний гарт, розвиток витривалості та сили духу. Загалом система військово-фрізичної підготовки дозволяла відпрацьовувати у молоді високу військову майстерність, формувати новий тип вояка - універсального, витривалого, готового до швидкої зміни обстановки, до відсічі ворогу часто у нерівному бою на суші та на воді» [4].

Другий період морської освіти в Україні - це час створення навчальних закладів для підготовки фрахівців морської справи. «Це пов'язано з тим, що після знищення Запорозької Січі та їі 
орлотилії Російська імперія розпочала інтенсивну колонізацію південноукраїнських земель. Тоді імперія розпочала побудову Чорноморського фллту й освоєння нових морських шляхів на ринки Азії та Європи. Більшість особового складу нового фрлоту - Азовської та Дніпровської фрлотилій - становили чорноморські та колишні запорізькі козаки» [4]. У другій половині XIX - першій чверті XX ст. однією 3 ключових ланок професійної освіти Херсонщини стали морські школи у Бериславі, Олешках і Голій Пристані, а також Херсонське училище далекого плавання. За короткий термін вони зміцнили матеріальну базу, укомплектувалися досвідченим викладацьким складом, підготували моряків- професіоналів високого гатунку [3].

Третій період розвитку морської освіти дослідниця слушно називає радянським. Упродовж цього періоду фрахівців для фллоту готували в корпусах (училищах), у яких пріоритетним напрямом було визначено широку універсалізацію.

Четвертий період розвитку морської освіти охоплює період із початку 90-х рр. XX ст. і донині, його, на нашу думку, можна визначити як розвиток української морської освіти [4].

У дослідженні будемо користуватися докладною періодизацією становлення й розвитку морської освіти України, розробленою в докторській дисертації А. Ляшкевич, котра виокремила шість періодів: І - стихійно-установчий (1830-ті - друга половина 1850-х рр.), точкове виникнення осередків освітньо-профресійного середовища морської освіти за відсутності єдиної програми її становлення; II - перший рефрорматорський (друга половина 1850-х - початок 1870-х рр.), зміна змісту діяльності закладів морського профрілю, що спричинена наслідками Кримської війни; III - другий рефрорматорський (початок 1870-х початок 1900-х рр.), побудова системи морської освіти на основі нової інструктивно-правової бази; IV - законодавчий (початок 1900-х - 1920 рр.), спроба сорормувати законодавчу базу морської освіти як складно структуровану частину професійною (з паузою 1917-1920рр.); V - пошуковоуніфрікаційний (1920-1991рр.), у межах якого визначено три субперіоди; VI - наслідувальнооновлювальний (1991-2013 рр.), розбудова національної, якісно нової системи морської освіти на підґрунті синтезу продуктивного досвіду минулого, сучасних інновацій і національних традицій (із паузою 1991-1995 рр.) [2].

Для нашого дослідження особливий інтерес викликав останній період, хронологічно співвіднесений із добою незалежності України.

Морська освіта незалежної України є багаторівневою та багатогалузевою й орієнтованою на європейські стандарти, оскільки реалізує всі етапі підготовки фрахівців, які мають змогу отримати як робочі профресії (з видачею відповідних свідоцтв), так і морські дипломи (рівнів експлуатації та управління).

Нормативно-правовою базою організації морської освіти є низка документів, передовсім Міжнародна Конвенція $з$ підготовки та надання дипломів морякам і несення вахт (прийнята ще 1978 р.), Міжнародний Кодекс із підготовки та надання дипломів морякам і несення вахт (ПДНВМ, щоправда зазначимо, що Україна приєдналася до ПдНВМ78 лише 1996 р.). Зазначимо, що 2010 р. було прийнято зміни до цих двох документів (т. зв. «Манільські поправки»), найбільш суттєвими 3-поміж яких було визначення нових посад для осіб командного складу й суднового екіпажу. Це зумовило необхідність фрормування нових складників професійної компетентності морських спеціалістів, передусім володіння англійською мовою - мовою міжнародного спілкування, а також вимог, які забезпечують підвищення рівня професіоналізму працівників морської галузі. Так, резолюцією 7 Конвенції встановлено відповідальність судноплавних компаній за добір і підготовку кадрів моряків, а також зазначено, що ефрективність процесів відбору, підготовки та дипломування моряків може бути оцінена лише внаслідок оцінювання навичок, умінь і компетентностей, які демонструють моряки у процесі виконання своїх профресійних обов'язків.

У незалежній Україні підготовку фрахівців, які здобувають морську освіту, здійснюють в академіях, університетах, коледжах. Наприклад, Херсонська державна морська академія має цікаву багаторічну історію: відкрита 1834 р. як морське училище, 1996 р. була реорганізована і стала морським коледжем, а за 10 років - Херсонським державним морським інститутом. Із 2011 р. - Херсонська державна морська академія.

Одеська морська академія також пройшла складний шлях перетворень від вищого морехідного училища до національного університету Національна Одеська морська академія.

У закладах морської освіти освітній процес спрямовано на формування ключових компетентностей, виділених Єврокомісією, до яких уналежнено технічну, природничо-наукову, комунікативну, математичну тощо, сорормованість яких сприяє забезпеченню якісної підготовки майбутніх фрахівців, профресійної готовності. Оскільки Україна входить до п'ятірки лідерів країн-постачальників командного персоналу для світового торгового фрлоту, фрормування ключових компетентностей студентів морських спеціальностей набуває особливої актуальності. Важливо сформувати в них усвідомлення соціальної значущості обраної профресії, бачення свого місця в системі професійних і соціальних відносин, здатність критично оцінювати життєвий і соціальний досвід, обирати продуктивні шляхи вдосконалення професійних якостей. 
Вивчення навчальних планів закладів морської освіти й організаційно-методичного забезпечення навчальних дисциплін професійного спрямування дозволило зробити висновок, що пріоритетним у роботі означених закладів є забезпечення високих стандартів профресійної підготовки, що є основою для надійної й безпечної галузі.

Сучасний транспортний фрлот у світовій морській індустрії $€$ найбільш складним і динамічним сегментом, оскільки постійно оновлюється спеціалізоване судноплавство, де застосовуються балкери, танкери, судна для транспортування розрідженого газу, автомобілів, контейнерів тощо, ускладнюється енергообладнання, його управління. Як уже зазначалося, Конвенція 1978 р. STCW(-78) встановила міжнародні стандарти освіти та професійної підготовки моряків, водночас зазнають змін стандарти стосовно енергозбереження й охорони довкілля. Це зумовлює необхідність уніфрікування програмово-методичного забезпечення освітнього процесу українських закладів морської освіти із зарубіжними.

Українські заклади морської освіти мають давні традиції відповідно до національних стандартів, але обов'язково враховують вимоги міжнародних стандартів. Прикметною ознакою сучасних закладів морської освіти є тісна міжнародна співпраця. Зазначимо, що всі вітчизняні заклади морської освіти мають угоди з різноманітними міжнародними організаціями й установами.

Вивчення досвіду роботи сучасних закладів морської освіти, спостереження за освітнім процесом уможливили виокремлення провідних напрямів їх діяльності, до яких відносимо:

- глобалізацію і різноаспектний розвиток морської освіти з поглибленням її теоретичних засад і розширенням практичного досвіду (кожен студент за час навчання здобуває потрібний стаж на судні та сучасних тренажерах й іншому обладнанні);

- кореляцію змісту робочих програм навчальних дисциплін із вимогами міжнародних стандартів і конвенцій;

- спрямованість на забезпечення безпеки судноплавства як через неухильне дотримання правил техніки безпеки, безаварійність, так і через застосування пристроїв і обладнання, що забезпечують безпеку для довкілля, тобто екологічну ефективність; випускники закладів морської освіти мають оволодіти технологіями, які задовольняють сучасні екологічні вимоги до транспортних засобів;

- посилення уваги до мовної освіти, зміщення акцентів у мовленнєвій підготовці студентів і занурення їх у професійний і полікультурний контексти; обов'язкове знання англійської мови як мови міжнародного спілкування;

- підготовку студентів до професійно й соціально відповідальної комунікації, зумовленої наці- онально змішаними колективами, які впродовж тривалого часу змушені працювати в обмеженому просторі;

- застосування в освітньому процесі інноваційних педагогічних технологій, спрямованих на фрормування ключових і професійних компетентностей випускників.

Вивчення досвіду роботи закладів морської освіти, активне міжнародне співробітництво, ресрормування системи морської освіти забезпечили міжнародне визнання української морської освіти, свідченням чого стало успішне проходження Україною інспектування з боку Європейської агенції морської безпеки (EMSA), що дало змогу українським морякам працювати на різних суднах під прапорами країн Європейського Союзу.

Традиційно із радянських часів лідером морської освіти в Україні була НУ «Одеська морська академія», якау своєму складі містить відокремлені структурні підрозділи, як-от Морехідний коледж технічного фрлоту й Морехідне училище імені Маринеско, кожне з яких має свої традиції та історію. Крім того, до складу вишу належать Азовський морський інститут (м. Маріуполь) і Дунайський інститут (м. Ізмаїл). Упродовж 1992-1998 рр. існувала фрілія в Києві, однак 1998 р. її було реорганізовано в Київську державну академію водного транспорту.

Нині високий рівень підготовки морських фрахівців здійснює Херсонська державна морська академія - державний заклад вищої освіти четвертого рівня акредитації. Навчальний заклад складається із трьох структурних підрозділів: Профресійно-морського ліцею ХДМА, Морського коледжу ХДМА та власне Академії. Навчально-тренажерна та лабораторна база ХДМА відповідає всім національним і міжнародним вимогам із підготовки морських фахівців, а деякі з наявних у ХДМА тренажерів не мають аналогів у морських навчальних закладах Європейського Союзу.

Звісно, перед закладами морської освіти ще стоїть багато проблем, пов'язаних із недостатнім фрінансуванням, кадровим забезпеченням, оновленням змісту фрахової підготовки.

Висновки. Отже, морська освіта - це не вузький галузевий напрям, а широке проблемне поле, яке потребує нових досліджень. Потребує більш докладного вивчення і світовий досвід підготовки фахівців, зокрема у Всесвітньому морському університеті (World Maritime University, WMU; (Мальме, Швеція), Інституті морських інженерів, заснованому у Великій Британії ще 1889 р., зараз його офріційна назва «Інститут морської інженерії, науки й технології» (Institute of Marine Engineering Science. Перспективи подальших розробок вбачаємо також у вивченні потенціалу морської освіти в контексті експорту освітніх послуг з огляду на відкритість світового ринку праці морських фрахівців. 
БІБЛІОГРАФІЧНИЙ СПИСОК:

1. Водотика С.Г., Сінкевич Є.Г. Історія Херсонщини : навчальний посібник. Херсон : Айлант, 2003. $202 \mathrm{c}$.

2. Ляшкевич A.I. Теорія і практика морської освіти півдня України (30-ті роки XIX - початок XXI століття) : дис. ... докт. пед. наук : 13.00.01. Тернопільський національний педагогічний університет імені Володимира Гнатюка, Міністерство освіти і науки України. Тернопіль, 2019. 616 с.

3. Нагрибельний Я.А. Розвиток професійної освіти на Херсонщині ц у другій половині XIX століття - на початку 1920-х рр. : дис. ... канд. істор. наук : 07.00.01. Чорноморський державний університет імені Петра Могили, Міністерство освіти і науки, молоді та спорту України. Миколаїв, 2012. 240 с.

4. Тимофеєєва О.Я. Історія морської освіти в Україні та сучасні наукові підходи до формування соціально-комунікативної компетентності майбутніх судноводіїв. Вісник Національної академії Державної прикордонної служби України. Пед. науки. 2015. Вип. 5.

5. Ходаковський В.Ф. Морський літопис (1834-2011): від училища торговельного мореплавства до Херсонської державної морської академії: нариси з історії. Херсон : ВНЗ «ХДМ|», 2011. 256 с. 